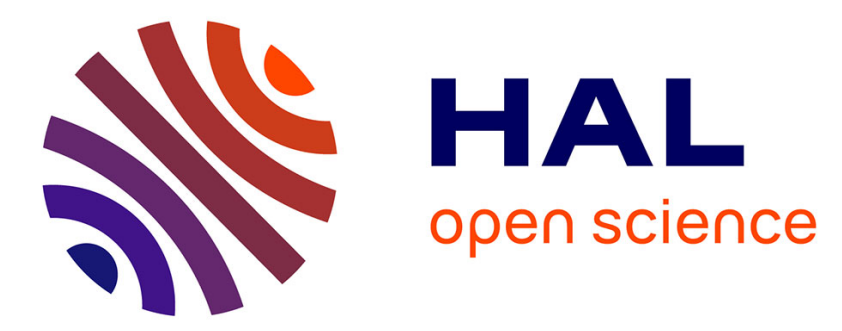

\title{
Murakami and H2SO4/H2O2 Pretreatment of WC-Co Hard Metal Substrates to Increase the Adhesion of CVD Diamond Coatings
}

\author{
R. Haubner, S. Kubelka, B. Lux, M. Griesser, M. Grasserbauer
}

\section{- To cite this version:}

R. Haubner, S. Kubelka, B. Lux, M. Griesser, M. Grasserbauer. Murakami and H2SO4/H2O2 Pretreatment of WC-Co Hard Metal Substrates to Increase the Adhesion of CVD Diamond Coatings. Journal de Physique IV Proceedings, 1995, 05 (C5), pp.C5-753-C5-760. 10.1051/jphyscol:1995589 . jpa-00253951

\section{HAL Id: jpa-00253951 https://hal.science/jpa-00253951}

Submitted on 1 Jan 1995

HAL is a multi-disciplinary open access archive for the deposit and dissemination of scientific research documents, whether they are published or not. The documents may come from teaching and research institutions in France or abroad, or from public or private research centers.
L'archive ouverte pluridisciplinaire HAL, est destinée au dépôt et à la diffusion de documents scientifiques de niveau recherche, publiés ou non, émanant des établissements d'enseignement et de recherche français ou étrangers, des laboratoires publics ou privés. 


\title{
Murakami and $\mathrm{H}_{2} \mathrm{SO}_{4} / \mathrm{H}_{2} \mathrm{O}_{2}$ Pretreatment of WC-Co Hard Metal Substrates to Increase the Adhesion of CVD Diamond Coatings
}

\author{
R. Haubner, S. Kubelka, B. Lux, M. Griesser* and M. Grasserbauer* \\ Institute for Chemical Technology of Inorganic Materials, Technical University of Vienna, Getreidemarkt \\ 9/161, 1060 Vienna, Austria \\ * Institute for Analytical Chemistry, Technical University of Vienna, Getreidemarkt 9/151, 1060 Vienna, \\ Austria
}

\begin{abstract}
Distinct improvement in adhesion of diamond coatings on hard metal substrates was achieved by following substrate surface pretreatment [1]:

First WC was removed from the substrate surface by etching with Murakami solution $\left(\mathrm{K}_{3}\left[\mathrm{Fe}(\mathrm{CN})_{6}\right]\right.$ in $\left.\mathrm{KOH}\right)$, after which the $\mathrm{Co}$ binder network was etched with $\mathrm{H}_{2} \mathrm{SO}_{4} / \mathrm{H}_{2} \mathrm{O}_{2}$ solution. Then diamond coatings were deposited on the substrates by hot-filament CVD.

Apparently during the $\mathrm{H}_{2} \mathrm{SO}_{4} / \mathrm{H}_{2} \mathrm{O}_{2}$ treatment of the $\mathrm{Co}$ binder a thin $\mathrm{CoO} / \mathrm{CoSO}_{4}$ film forms, which prior to the diamond deposition would be reduced to $\mathrm{CoS}$ by the hydrogen and carbon species involved in the diamond synthesis. Since $\mathrm{CoS}$ is a stable compound at the diamond deposition temperatures, its $C_{0}$ vapor pressure and the $C_{0}$ surface mobility should be substantially lower than that for metallic $\mathrm{Co}$. Thus the diamond/hard metal interface is no longer influenced detrimentally by the metallic Co binder. This explanation has however not yet been confirmed by analytical methods such as SIMS and XPS.

An alternative explanation would be the increased roughness of the hard metal surface resulting from the removal of the Co binder and the formation of deep grooves on the interface which could lead to the improved adhesion. This however does not explain why Co migration and other detrimental effects are not observed.
\end{abstract}

\section{INTRODUCTION}

CVD diamond coatings can be expected to significantly prolong the lifetime of coated tools during cutting and milling of non-ferrous materials such as Al(Si) alloys, graphite and plastics [2-6].

The $\mathrm{Co}_{0}$ in the hard metal binder phase can however detrimentally influence the chemical vapor deposition of diamond [7-10]. Co vapor pressure, surface migration, and carbon solubility are the main parameters influencing diamond nucleation and growth and coating adhesion [11-14].

The application of intermediate layers is one promising technique for the deposition of more adherent diamond films [15]. Petreatment procedures are usually aimed at depleting the Co in the substrate surface by selective chemical etching [11,16-18]. A new approach to improve diamond coating adhesion involves the formation of Co compounds such as borides and silicides [19] which are stable under diamond deposition conditions.

In this paper the special surface pretreatment procedure reported in the patent [1] was investigated. After small amounts of WC are removed from the hard metal substrate surface by etching with Murakami solution $\left(\mathrm{K}_{3}\left[\mathrm{Fe}(\mathrm{CN})_{6}\right]\right.$ in $\left.\mathrm{KOH}\right)$, the remaining Co binder network is treated with $\mathrm{H}_{2} \mathrm{SO}_{4} / \mathrm{H}_{2} \mathrm{O}_{2}$ solution. The effects of this surface treatment with respect to diamond growth rate, morphology and adhesion of the deposited coating on the substrates were investigated and SIMS depth profiles were used to characterize the substrate/coating interface. 


\section{EXPERIMENTAL DETAILS}

\subsection{Substrate surface pretreatment and diamond deposition apparatus}

Indexable hard metal inserts from Teledyne Firth Sterling, La Vergne, TN, USA (grade SPGN 120308 , quality $\mathrm{H} 21 ; 94 \% \mathrm{WC}, 5.5 \% \mathrm{Co}, 0.5 \%(\mathrm{Ta}, \mathrm{Nb}) \mathrm{C}[20])$ were used as substrates. They were ultrasonically cleaned in acetone prior to pretreatment. The Murakami solution $\left(10 \mathrm{~g} \mathrm{~K}_{3}\left[\mathrm{Fe}(\mathrm{CN})_{6}\right], 10 \mathrm{~g} \mathrm{KOH}\right.$, $\left.100 \mathrm{ml} \mathrm{H} \mathrm{H}_{2} \mathrm{O}\right)$ and the $\mathrm{H}_{2} \mathrm{SO}_{4} / \mathrm{H}_{2} \mathrm{O}_{2}\left(5 \% \mathrm{H}_{2} \mathrm{SO}_{4}\right.$ in $\left.35 \% \mathrm{H}_{2} \mathrm{O}_{2}\right)$ solution were prepared just before the etching treatment. Between the etching steps the substrates were cleaned with water. No diamond scratching, bias treatments or other nucleation enhancements were applied.

The diamond deposition experiments were carried out in a hot-filament CVD reactor as described elsewhere [21-23]. A coiled tantalum filament was used and its temperature was measured by a two-color pyrometer (IRCON with Mirage OR 15 sensor).

The substrates were placed on the molybdenum substrate holder situated $10 \mathrm{~mm}$ from the filament. The substrate surface temperature was measured by a $\mathrm{Ni} / \mathrm{CrNi}$ thermocouple positioned in a dummy substrate located about $0.2 \mathrm{~mm}$ under the substrate surface [23]. For each diamond deposition experiment two substrates were placed on either side of this dummy.

\subsection{Examinations}

\subsubsection{Characterization of the diamond deposits}

SEM was used to study the morphologies of the deposited layers and to measure the nucleation density when only individual crystals were obtained. The diamond growth rates were calculated from the weight differences of the substrates before and after deposition [22].

The adhesion of the diamond coatings was estimated from a Rockwell A test (test load 62.5 kg) [24] as well as from a manual scratch test with a diamond stylus [11].

Cutting tests were done by Teledyne Firth Sterling, La Vergne, TN, USA under the following conditions: Reynolds 390 alloy (18\% Si), 1250 surface $\mathrm{ft} / \mathrm{min}(380 \mathrm{~m} / \mathrm{min}), 0.05$ in $(1.3 \mathrm{~mm})$ depth of cut and $0.10 \mathrm{in} / \mathrm{rev}(2.5 \mathrm{~mm} / \mathrm{rev})$ feed.

\subsubsection{SIMS analysis}

SIMS measurements were performed using a CAMECA ims 3 f ion microscope $[25,26] . \mathrm{An}_{2}^{+}$or a $\mathrm{Cs}^{+}$ primary beam was applied to sputter the samples. The rastered area varied between $300 \times 300$ and $500 \mathrm{x}$ $500 \mu^{2}$ for an analyzed area $60 \mu \mathrm{m}$ in diameter. Positive secondary ions of the masses $12(\mathrm{C}), 59(\mathrm{Co})$, $182(\mathrm{~W}), 184(\mathrm{~W})$ were detected with $\mathrm{O}_{2}{ }^{+}$-bombardement, while negative secondary ions of the masses $16(\mathrm{O}), 75(\mathrm{CoO})$ and $91(\mathrm{CoS})$ were measured using $\mathrm{Cs}^{+}$ions.

The $\mathrm{C}$ signal was used as a reference for the diamond matrix and to locate the diamond/hard metal interface. Because of the high intensity of $\mathrm{Co}$ and $\mathrm{W}$, energy filtering was applied to keep the signals in the dynamic range of the electron multiplier which was used as a secondary ion detector [27]. For W the offset was $-75 \mathrm{~V}$ and two isotopes (masses 182 and 184) were measured to verify via the relative isotopic abundance that tungsten was detected.

In the case of Co only ions with a kinetic energy above 75 or $125 \mathrm{eV}$ were detected. This was necessary because there is only one Co isotope at $\mathrm{m} / \mathrm{e}=59$. The observation of parallel signals indicated that Co was detected.

The nominal depth resolution was approximately $30 \mathrm{~nm}$ for flat samples. In practical operation however the depth resolution was limited due to the roughness of the specimens. The sputter rates of the relevant materials were determined via the measurement of the crater depth by a surface profilometer (Sloan Dektak IIA). For the applied measurement parameters the sputter rates were found to be $0.4 \mathrm{~nm} / \mathrm{s}$ $\left(\mathrm{O}_{2}^{+}\right)$and $3 \mathrm{~nm} / \mathrm{s}\left(\mathrm{Cs}^{+}\right)$for diamond and $0.6 \mathrm{~nm} / \mathrm{s}\left(\mathrm{O}_{2}{ }^{+}\right)$for the hard metal substrate. 


\section{RESULTS}

\subsection{Substrate surface treatment by etching with Murakami and $\mathrm{H}_{2} \mathrm{SO}_{4} / \mathrm{H}_{2} \mathrm{O}_{2}$}

During the Murakami etching [1] WC particles are dissoluted, leaving behind the Co network from the binder phase. In the second step the $\mathrm{Co}$ binder phase is attacked by $\mathrm{H}_{2} \mathrm{SO}_{4} / \mathrm{H}_{2} \mathrm{O}_{2}$ and in the $10 \mathrm{sec}$ etching time $\mathrm{Co}$ is partially dissolved from the surface and can also react to form $\mathrm{CoSO}_{4}$.

Figure 1 shows the surfaces of the hard metal substrates after various etching treatments.

The WC etching effect by the Murakami solution was obvious after 5 minutes. During longer etching times the surface morphology did not change dramatically.

$10 \mathrm{sec} \mathrm{H}_{2} \mathrm{SO}_{4} / \mathrm{H}_{2} \mathrm{O}_{2}$ etching hardly affected the original hard metal substrates. The Co binder phase was still present at the substrate surface. In the case of a prior Murakami treatment the etching for $10 \mathrm{sec}$ with $\mathrm{H}_{2} \mathrm{SO}_{4} / \mathrm{H}_{2} \mathrm{O}_{2}$ produced fewer morphological changes in the substrate surface. Microprobe measurements showed that the Co content at the substrate surface decreased rapidly, but no $\mathrm{S}$ (from $\mathrm{SO}_{4}{ }^{2-}$ ) could be detected [28].

SIMS depth profiles measured by an $\mathrm{O}_{2}^{+}$primary beam (Figure 2 ) clearly showed an increase of Co at the substrate surface after Murakami etching and a strong decrease of Co after the $\mathrm{H}_{2} \mathrm{SO}_{4} / \mathrm{H}_{2} \mathrm{O}_{2}$ etching. Because $\mathrm{O}$ and $\mathrm{O}$ compounds cannot be detected by an $\mathrm{O}_{2}{ }^{+}$primary beam, measurements with a Cs ${ }^{+}$ primary beam were also performed to obtain more information about the formation of $\mathrm{CoSO}_{4}$ or oxides (Figure 3). With these measurements three regions could be identified: At the substrate surface low Co and $\mathrm{CoO}$ were observed which can be explained by the surface etching. Below the surface an area with maximal $\mathrm{CoO}$ concentrations was observed. Under this zone the hard metal bulk material began and all concentrations were constant. The $\mathrm{CoS}$ and $\mathrm{S}$ ions were also measured but due to the $\mathrm{O}_{2}$ interference $\mathrm{S}$ could not be detected clearly.

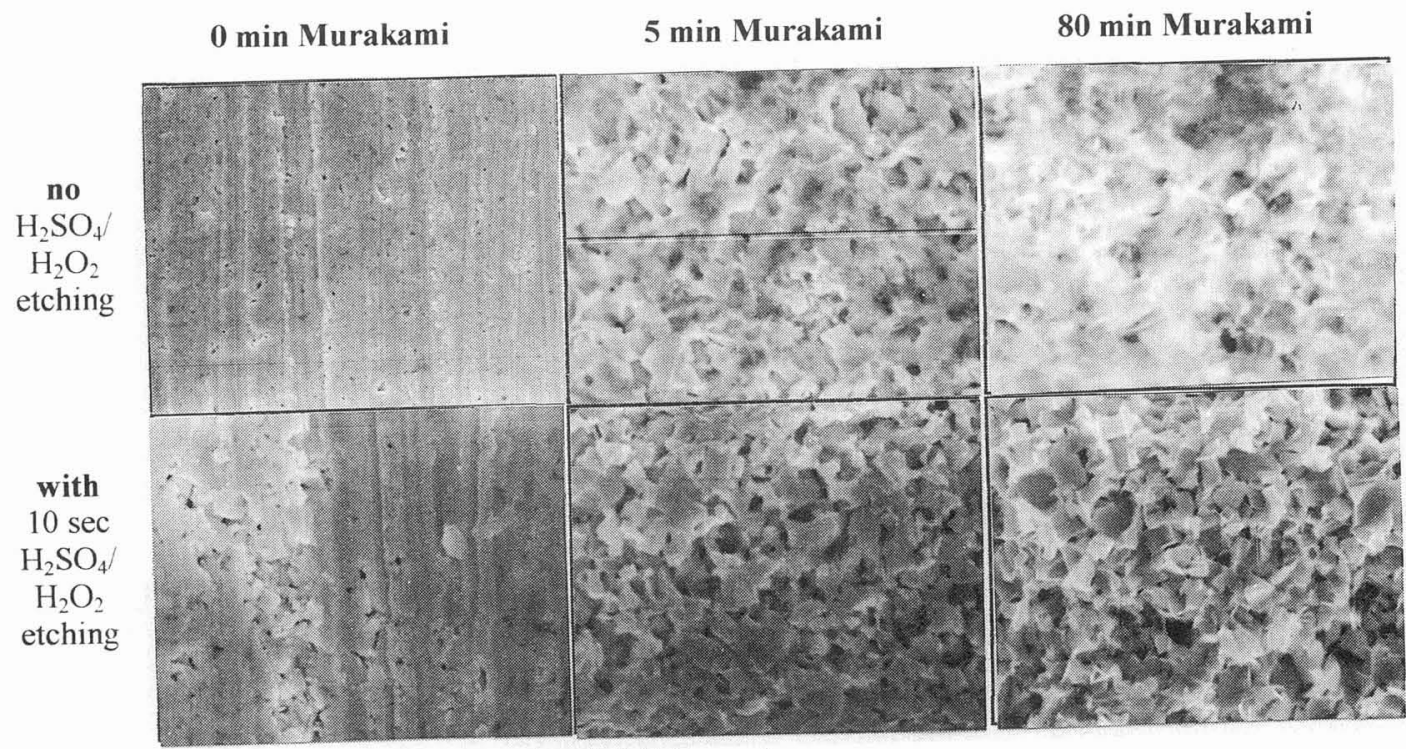

Figure 1: The surfaces of the hard metal substrates after various etching treatments 

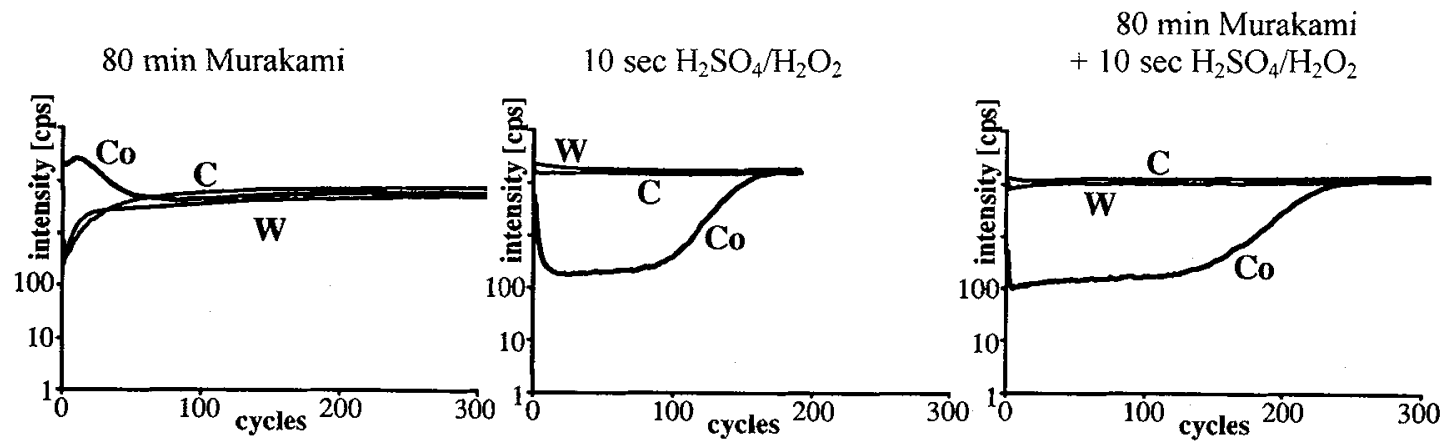

Figure 2: SIMS depth profiles of the hard metal substrates after various surface treatments $\left(\mathrm{O}_{2}{ }^{+}\right.$primary beam)

5 min Murakami $+10 \mathrm{sec} \mathrm{H}_{2} \mathrm{SO}_{4} / \mathrm{H}_{2} \mathrm{O}_{2}$

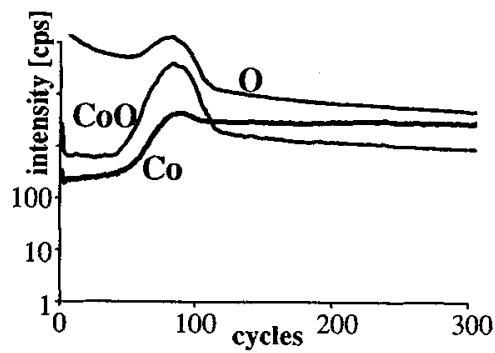

80 min Murakami $+10 \mathrm{sec} \mathrm{H}_{2} \mathrm{SO}_{4} / \mathrm{H}_{2} \mathrm{O}_{2}$

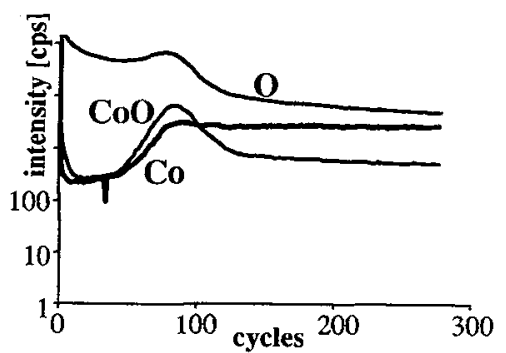

Figure 3: SIMS depth profiles of the substrates after different surface treatments $\left(\mathrm{Cs}^{+}\right.$primary beam)

\subsection{Diamond deposition}

Following the various etching treatments the substrates were coated with diamond for 5 or 16 hours to investigate diamond nucleation, diamond growth rate, morphology and adhesion of each deposited diamond layer (Table 1, Figure 4).

Murakami etching: After this treatment and $5 \mathrm{~h}$ deposition the diamond particle density was very high (about $10^{7} / \mathrm{cm}^{2}$ ) but among the diamond crystals, which were not always faceted, ballas-type particles were also observed. After $16 \mathrm{~h}$ deposition well-faceted diamond layers were deposited but the adhesion was very poor. These coatings flaked off during cooling so that it was impossible to measure the diamond growth rates.

$10 \mathrm{sec} \mathrm{H}_{2} \mathrm{SO}_{4} / \mathrm{H}_{2} \mathrm{O}_{2}$ etching: The diamond particle density after $5 \mathrm{~h}$ was about $6 \times 10^{6} / \mathrm{cm}^{2}$. The diamond crystals were already well faceted and no $\mathrm{Co}$ influences could be observed. For $16 \mathrm{~h}$ deposition the diamond growth rate was $0.54 \mathrm{mg} / \mathrm{h}$. Although these coatings adhered after deposition, large patches flaked off after the Rockwell indentation tests.

Combined Murakami and $\mathrm{H}_{2} \mathrm{SO}_{4} / \mathrm{H}_{2} \mathrm{O}_{2}$ etching: The Murakami solution was applied between 0 and $80 \mathrm{~min}$ while the $\mathrm{H}_{2} \mathrm{SO}_{4} / \mathrm{H}_{2} \mathrm{O}_{2}$. step was uniformly $10 \mathrm{sec}$. The diamond particle density after $5 \mathrm{~h}$ deposition was $4-7 \times 10^{6} / \mathrm{cm}^{2}$ on substrates etched for $0-30$ min with Murakami. A strong increase in particle density up to $1.3 \times 10^{7} / \mathrm{cm}^{2}$ was observed on substrates etched for $50 \mathrm{~min}$ in Murakami; for $80 \mathrm{~min}$ layer formation was observed after only $5 \mathrm{~h}$ deposition. The diamond growth rates measured after $16 \mathrm{~h}$ deposition showed a maximum for 20 min Murakami etching. Diamond adhesion was good: all of these diamond coatings survived the Rockwell test intact.

SIMS measurements: Figure 5 compares the SIMS depth profiles of diamond coatings on substrates given various pretreatments. SIMS profiles of diamond coatings on untreated hard metals [21] and on Bor Si-pretreated hard metal substrates [19] are not discussed here. 
Depth profiles of $\mathrm{C}, \mathrm{W}$, and Co: Because of the different diamond growth rates on the substrates the layer thicknesses were not uniform. The varying surface roughnesses also influenced the profiles. The profiles indicated that the diamond / hard metal interface is reached when the W signal intensity increases and simultaneously the $\mathrm{C}$ signal decreases. The greatest differences were found in the Co signal, which did not reach its constant value at the interface, where it was much lower than in the hard metal bulk material. In two samples the Co signal was also observed in the diamond layer.

Table 1: Results of diamond deposition on WC-Co substrates pretreated with Murakami and $\mathrm{H}_{2} \mathrm{SO}_{4} / \mathrm{H}_{2} \mathrm{O}_{2}\left(\mathrm{~T}_{\text {fil }}=2400^{\circ} \mathrm{C}, \mathrm{T}_{\text {sub }}=900^{\circ} \mathrm{C}, 1 \% \mathrm{CH}_{4}, \mathrm{p}=20\right.$ torr $)$

\begin{tabular}{|c|c|c|c|c|c|c|c|}
\hline & & & h deposit & & & deposition & \\
\hline $\begin{array}{l}\text { etching } \\
\text { Murakami } \\
\text { [min] }\end{array}$ & $\begin{array}{l}\text { etching } \\
\mathrm{H}_{2} \mathrm{SO}_{4} / \mathrm{H}_{2} \mathrm{O}_{2} \\
\text { [sec] }\end{array}$ & $\begin{array}{c}\text { diamond } \\
\text { growth } \\
\text { rate } \\
{[\mathrm{mg} / \mathrm{h}]} \\
\end{array}$ & $\begin{array}{c}\text { particle } \\
\text { density } \\
{\left[\times 10^{6} / \mathrm{cm}^{2}\right]}\end{array}$ & morphology & $\begin{array}{l}\text { diamond } \\
\text { growth } \\
\text { rate } \\
\text { [mg/h] }\end{array}$ & morphology & $\begin{array}{l}\text { coating } \\
\text { adhesion }\end{array}$ \\
\hline 5 & 0 & 0.54 & 8 & fac.+ballas & - & faceted layer & poor \\
\hline 80 & 0 & 0.64 & layer & fac. +ballas & -- & faceted layer & poor \\
\hline 0 & 10 & 0.40 & 6 & faceted & 0.54 & faceted layer & medium \\
\hline 5 & 10 & 0.44 & 6 & faceted & 0.56 & faceted layer & good \\
\hline 10 & 10 & 0.32 & 4 & faceted & 0.68 & faceted layer & good \\
\hline 20 & 10 & 0.28 & 5 & faceted & 0.79 & faceted layer & good \\
\hline 30 & 10 & 0.36 & 7 & faceted & 0.69 & faceted layer & good \\
\hline 50 & 10 & 0.38 & 13 & faceted & 0.63 & faceted layer & good \\
\hline 80 & 10 & 0.52 & layer & faceted & 0.64 & faceted layer & good \\
\hline
\end{tabular}

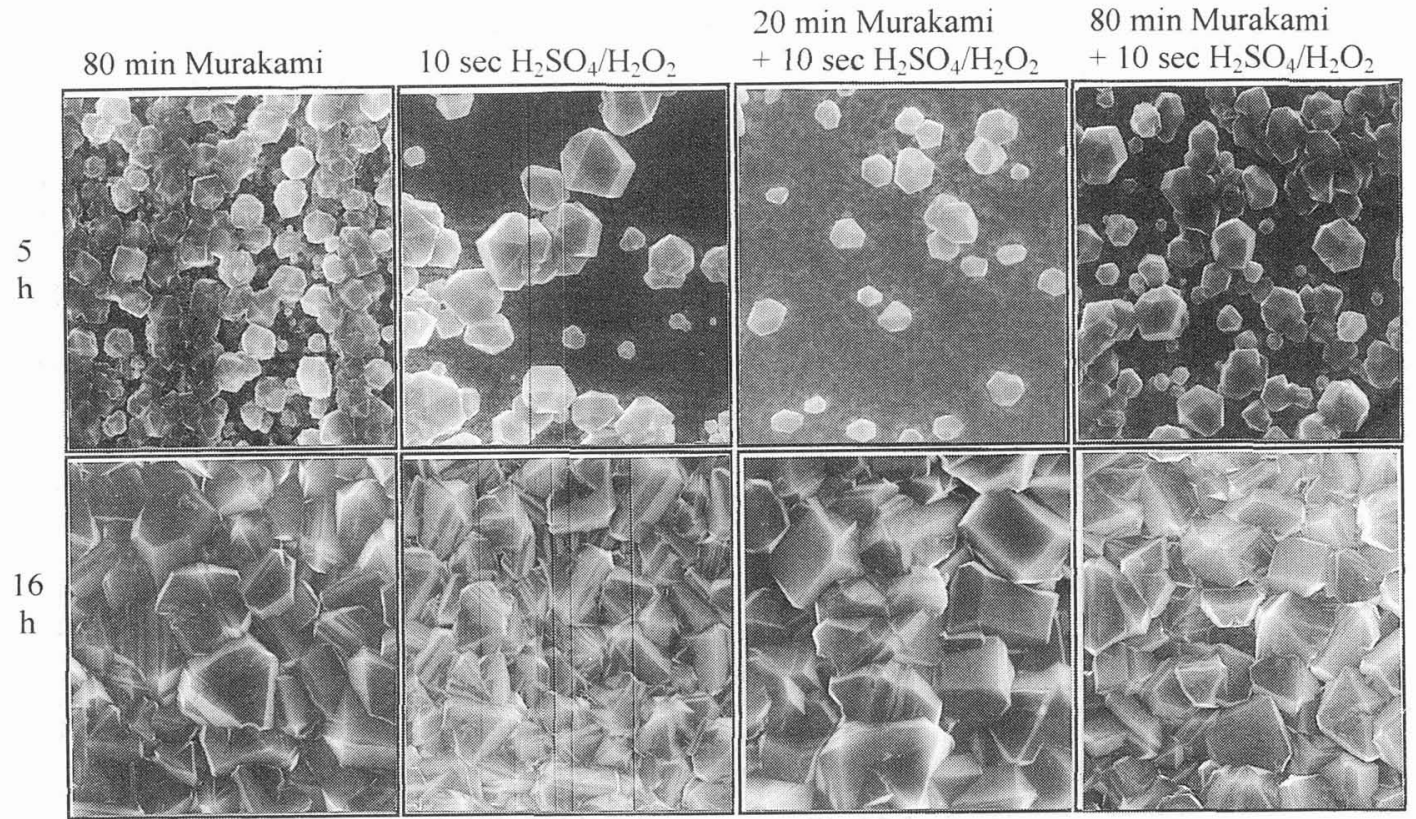

Figure 4: Diamond deposition on hard metal substrates after different etching treatments ( 5 and $16 \mathrm{~h} ; \mathrm{T}_{\text {fil }}=2400^{\circ} \mathrm{C}, \mathrm{T}_{\text {sub }}=900^{\circ} \mathrm{C}, 1 \% \mathrm{CH}_{4} \mathrm{p}=20$ torr $)$ 
$\begin{array}{lll} & 5 \text { min Murakami } & 80 \text { min Murakami } \\ 10 \mathrm{sec} \mathrm{H}_{2} \mathrm{SO}_{4} / \mathrm{H}_{2} \mathrm{O}_{2} & +10 \mathrm{sec} \mathrm{H}_{2} \mathrm{SO}_{4} / \mathrm{H}_{2} \mathrm{O}_{2} & +10 \mathrm{sec} \mathrm{H}_{2} \mathrm{SO}_{4} / \mathrm{H}_{2} \mathrm{O}_{2}\end{array}$
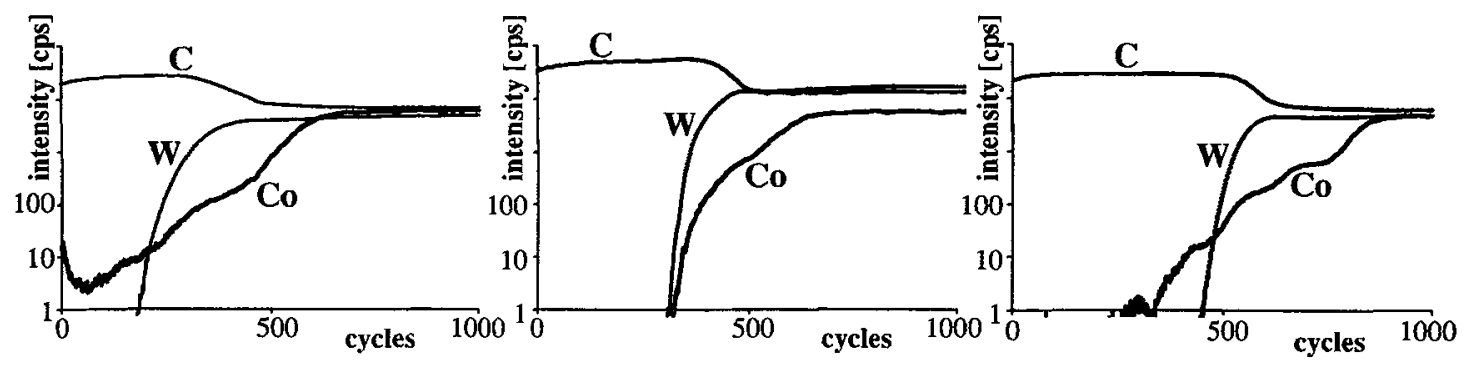

Figure 5: SIMS depth profiles of the hard metal substrates after various surface treatments

( $16 \mathrm{~h}$ deposition; $\mathrm{T}_{\mathrm{fil}}=2400^{\circ} \mathrm{C}, \mathrm{T}_{\mathrm{sub}}=900^{\circ} \mathrm{C}, 1 \% \mathrm{CH}_{4}, \mathrm{p}=20$ torr $)$

\section{DISCUSSION}

Diamond deposition on hard metals is of industrial interest for wear applications. However, for long tool life the well known detrimental influences of $\mathrm{Co}$ on the diamond morphology and adhesion must be overcome [7-10]. In the present work the Murakami $-\mathrm{H}_{2} \mathrm{SO}_{4} / \mathrm{H}_{2} \mathrm{O}_{2}$ etching procedure [1] was used to reduce the Co effects and to facilitate the study of diamond nucleation and growth.

\subsection{The etching procedure}

This method combining Murakami and $\mathrm{H}_{2} \mathrm{SO}_{4} / \mathrm{H}_{2} \mathrm{O}_{2}$ etching is necessary to reduce the metallic Co content on the surface and establish stable surface conditions.

Etching with Murakami alone merely increases the Co concentration at the substrate surface by removing WC.

$\mathrm{H}_{2} \mathrm{SO}_{4} / \mathrm{H}_{2} \mathrm{O}_{2}$ alone results in much less etching due to the smooth substrate surface and less $\mathrm{CoSO}_{4}$ and/or Co-oxide formation.

The Murakami etching as a first step however increases the substrate surface roughness, providing a large surface area which can be easily attacked by the $\mathrm{H}_{2} \mathrm{SO}_{4} / \mathrm{H}_{2} \mathrm{O}_{2}$ solution. The Co network is dissolved by the acid and more $\mathrm{Co}$ is available to form $\mathrm{CoSO}_{4}$ and $\mathrm{Co}$ oxides.

The SEM pictures (Figure 1) show mainly a rough substrate surface without well-faceted WC crystals since the Murakami etching removed any WC crystal facets that were present. The SIMS depth profiles also show a reduction of $\mathrm{Co}$ at the substrate surface, indicating that $\mathrm{Co}$ is etched from the substrate surface and transformed into $\mathrm{CoSO}_{4}$ and/or $\mathrm{Co}$ oxides even below the substrate surface.

\subsection{Diamond deposition}

During diamond deposition the $\mathrm{CoSO}_{4}$ and the Co oxides are quickly reduced by the (atomic) hydrogen, forming $\mathrm{CoS}$ and $\mathrm{Co}$. As discussed earlier [19] Co compounds reduce both the Co vapor pressure and mobility during diamond deposition, leading to better diamond quality and better adhesion. This explanation has however not yet been confirmed by conclusive analytical methods as SIMS or XPS [28]. The increased roughness of the hard metal surface and the formation of deep grooves on the interface by the removal of the Co binder could also lead to improved adhesion. However, this alternate explanation does not account for the absence of Co migration or other detrimental Co effects.

Figure 6 illustrates the effects occurring during substrate pretreatment and diamond deposition. 

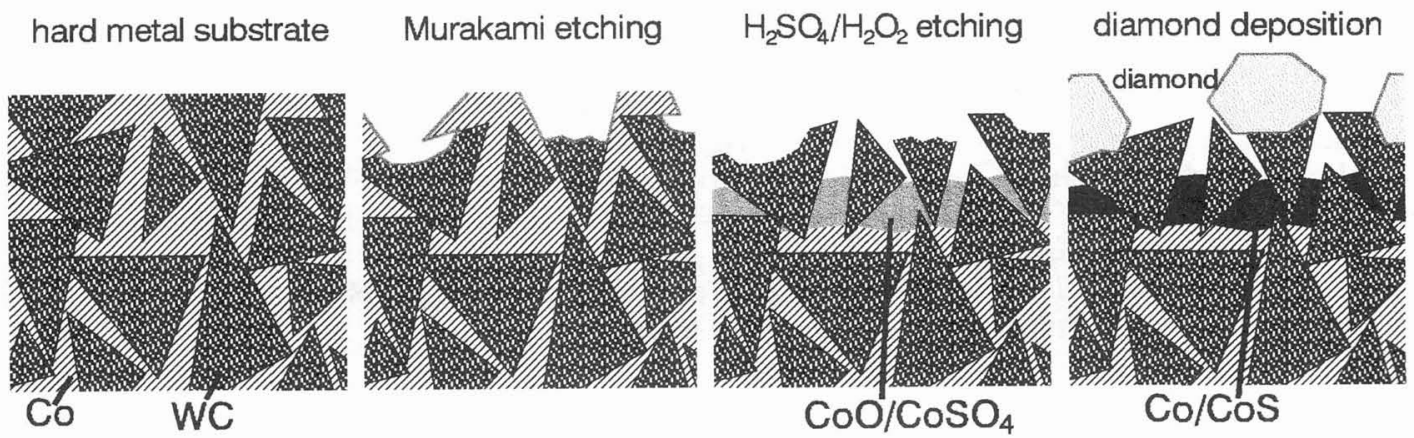

Figure 6: Effects occurring during etching and diamond deposition

\subsubsection{Diamond nucleation and growth}

With the surface pretreatment diamond nucleation could take place as discussed for inert substrates [14]: The nuclei grow to individual crystals which later grow together to form a diamond layer. During this time the $\mathrm{CoS}$ protects the growing diamond. Both Co migration on the surface and the Co vapor pressure are reduced and no Co influences on the diamond coating could be observed. After the diamond coating has become continuous the growth rate is no longer influenced by the substrate, depending only on the diamond deposition conditions [14].

\subsubsection{Adhesion between diamond layer and substrate}

As already known [21] the Co binder phase is important for coatings since it fills the voids between the diamond crystals and so increases the adhesion. If these voids are reduced and the diamond / substrate interface becomes smooth the adhesion decreases [21]. The tendency of Co vapor to enhance the formation of non-diamond carbon at the interface also reduce the adhesion [9].

The influence of Co must however be suppressed during diamond nucleation and until a continuous layer has formed, after which Co should enhance the adhesion between the coating and the substrate.

The $\mathrm{CoS}$ formed during diamond deposition fulfills these requirements very well.

Rockwell indentation tests showed that the adhesion of the diamond layers deposited after the combined Murakami $+\mathrm{H}_{2} \mathrm{SO}_{4} / \mathrm{H}_{2} \mathrm{O}_{2}$ etching treatment was much better than on untreated WC-Co substrates. Short 3 -minute cutting tests showed that the coatings have good wear resistance and adhesion.

\section{CONCLUSION}

Diamond deposition on hard metal substrates can be influenced by a surface pretreatment with Murakami and $\mathrm{H}_{2} \mathrm{SO}_{4} / \mathrm{H}_{2} \mathrm{O}_{2}$ etching. The detrimental influence of $\mathrm{Co}$ as observed on untreated substrates could be reduced. Diamond layers up to $16 \mu \mathrm{m}$ thick showed better adhesion on pretreated substrates. The number of diamond crystals nucleated and the diamond growth rate were also higher on such substrates.

SIMS depth profiles confirmed changes in the Co binder phase composition during both the etching pretreatment and the diamond deposition. $\mathrm{CoS}$ formed from $\mathrm{CoSO}_{4}$ should be the most stable Co compound in this system. CoS is very difficult to detect by SIMS and XPS but other analytical methods to identify it are being developed.

There are 3 common pretreatments for hard metals:

(1) etching of the Co binder $[10,16,17]$

(2) intermediate layers $[15,29]$

(3) fixing the Co by forming stable compounds [19]

The present method combines (1) and (3), whereby the more significant aspect should be the formation of the stable CoS which reduces the Co effects. 


\section{Acknowledgment}

The authors gratefully acknowledge financial support of the present work by Balzers, Liechtenstein. We especially thank Dr.H.Kaufmann for his interest in our work.

We also acknowledge financial support by the Austrian Science Foundation (FWF; Project 5902) carried out under the auspices of the trinational "D-A-CH" German, Austrian and Swiss cooperation on the "Synthesis of Superhard Materials".

Thanks also go to Dr.B.Kieffer and Dr.J.J.Oakes (Teledyne Firth Sterling, USA) for providing the hard metal substrates and performing the cutting tests free-of-charge.

\section{References}

[1] Peters M.G. and Cummings R.H., European Patent No. 0519587 A1 (1992)

[2] Lux B. and Haubner R., "Diamond Films, Coatings", Editor: R.F.Davis; NOYES Publications Park Ridge, New Jersey, USA (1993) pp.184-243

[3] Murakawa M. and Takeuchi S., Surf. Coat. Technol., 49 (1991) 359-365

[4] Oakes J., Pan X.X., Bichler R., Haubner R. and Lux B., Surf. Coat. Technol., 47 (1991) 600-607

[5] Bull S.J. and Matthews A., Diamond and Related Materials, I (1992) 1049-1064

[6] Schachner H., Lux B., Stjernberg K., Thelin A. andTippmann H., European Patent 166708 (1986)

[7] Haubner R. and Lux B., Journal de Physique C5 (1989) 169-176

[8] Haubner R., Lindlbauer A. and Lux B., Diamond and Related Materials, 2 (1993) 1505-1515

[9] Matsubara H. and Kihara J., "Science, Technology of New Diamond", KTK Scientific Publishers, Tokyo (1990) S.Saito, O.Fukunaga, M. Yoshikawa Eds, pp.89-93

[10] Huang T.H., Kuo C.T., Chang C.S., Kao C.T. and Wen H.Y., Diamond and Related Materials, 1 (1992) 594-599

[11] Pan X.X., Doctoral Thesis, Technical University of Vienna (1989)

[12] Park B.S., Baik Y-J., Lee K-R., Eun K.Y. and Kim D.H., Diamond and Related Materials, 2 (1993) 910-917

[13] Matsubara H. and Sakuma T., J. Mater. Sci, 25 (1990) $4472-4476$

[14] Bichler R., Haubner R. and Lux B., High Temperature-High Pressure, 21 (1989) 576-593

[15] Isozaki T., Saito Y., Masuda A., Fukumoto K., Chosa M., Ito T., Oles E.J., Inspector A. and Bauer C.E., Diamond and Related Materials, 2 (1993) 1146-1159

[16] Shibuki K., Yagi M.,.Saijo K and Takatsu S., Surf. Coat. Technol., 36 (1988) 295-302

[17] Mehlmann A.K., Dirnfeld S.F.and Avigal Y., Diamond and Related Materials, 1 (1992) 600-604

[18] Park B.S., Baik Y.-J., Lee K.-R., Eun K.Y. and Kim D.H., Diamond and Related Materials, 2 (1993) 910-917

[19] Kubelka S., Haubner R., Lux B., Steiner R., Stingeder G. and Grasserbauer M., Diamond and Related Materials, 3 (1994) 1360-1369

[20] Schedler W., Hartmetall für den Praktiker pp.43-46, Editor: Plansee TIZIT GmbH, VDI-Verlag, Düsseldorf, Germany (1988)

[21] Kubelka S., Haubner R., Lux B., Steiner R., Stingeder G. and Grasserbauer M., Diamond Films and Technology (in press)

[22] Brunsteiner R., Haubner R. and Lux B., Diamond and Related Materials, 2 (1993) 1263-1270

[23] Haubner R., Okoli S. and Lux B., Refractory Metals and Hard Materials, 11 (1992) 259-265

[24] Jindal P.C., Quinto D.T. and Wolfe G.J., Thin Solid Films, 154 (1987) 361-375

[25] Benninghoven A., Rüdenauer F.G. and Werner H.W., Secondary Ion Mass Spectrometry, Vol. 68 in Chemical Analysis, John Wiley \& Sons, New York, USA (1987)

[26] Grasserbauer M., Stingeder G, Friedbacher G. and Virag A., Surf. Interface Anal. 14 (1989) 623

[27] Wittmack K., Appl. Phys. Lett. 9 (1976) 552

[28] Ley L., Stöckel R., University of Erlangen (Germany), private communication (1995)

[29] Kubelka S., Doctoral Thesis, Technical University of Vienna (1994) 